\title{
Sound Codes in Advertising
}

\section{Natalya Fridrikhovna Bolshakova}

Perm National Research Polytechnic University

Email: natalyabolshakov@yandex.ru

\section{Doi:10.5901/mjss.2015.v6n3s4p75}

\begin{abstract}
The article is dedicated to research into the effect of a sound and musical accompaniment in a TV commercial. But for verbal components of advertisement intended to affect a person by means of words non-verbal components serve the same purpose. It is important to notice that non-verbal part of advertisement does not only form the background for the text but makes its own message involving the consumer into the non-verbal communication process. As long as a commercial contains minimum two messages (verbal and non-verbal) it has a real impact on the consumer provided these messages do not counteract but harmoniously complete each other. An experiment on a commercial perception with no video series has been conducted. The objective is to demonstrate effectiveness of a sound accompaniment in commercials. The issue is of paramount importance today because of lack of information in this sphere, its low level of scrutiny and a small amount of research.
\end{abstract}

Keywords: advertising, sound code, music line, informational orientation, audio branding.

\section{Introduction}

Advertising appears to be one of the most highly demanded aspects of business today since no commercial enterprise becomes successful without a firm positioning at the labour-market. Advertising is brief fancy information about a product or service aimed at potential buyers and focused on catching their attention and influencing their purchasing behaviour. "Unfolding" an advertisement copy, one can observe that it comprises more than just an appeal for buying a product. Commercial together with a product offers to grow familiar with a new world by means of "magic by analogy". It forms consumer's principles and lifestyle through figurative thinking, thus making the process even more successful since a person hardly realizes it, supposes S. Grachyova (Grachyova, 1997).

The issue of attracting a consumer's attention to commercial seems to be acute indeed. Apart from verbal components that influence a consumer through words, non-verbal elements are aimed at exactly the same effect. In an advertisement copy these components serve as one semantic and functional ensemble, producing an integrated impact on a recipient (Pishcherskaya, 2011).

A non-verbal part of a commercial not only provides a background for the text but also forms its own message, thus involving a consumer in the process of non-verbal communication.

Today specialists pay heed to a video component more than that of a musical one (Batra \& Aaker, 1999; Pocheptsov, 2000 \& Feofanov, 2000). At the same time a sound is one of the most primal instruments of inviting a consumer's attention to commercial. Music (and a sound as such) has a huge effect on the conscious and the subconscious, on a human's behavioral patterns and through this even on some definite social processes. It is no coincidence that such notion as "audio branding" has gained popularity recently.

In business audio branding is used as a harmonious addition to a product's image with the help of sounds, which, according to Goncharov P. A. and Basov D. D. (Goncharov \& Basov), allows to tackle the following issues:

- creating essential associations with a brand

- creating a definite emotional perception of a brand

- correction of purchasing behaviour

- boosting brand's notability

- perfecting the procedure of interaction with brand's products

Audio features set a consumer in the right mood and excite certain emotions practically right away. A sound impact on purchasing behaviour has become an object for a number of research studies, which testifies to effectiveness and importance of audio branding:

- music and its rhythm can affect the speed at which a consumer moves around while buying something (slow music incites people to stay at a restaurant longer and spend more money on spirits) (Feofanov, 1993); 
- loud music fosters ordering drinks at the bar (Areni \& Kim, 1993);

- music can stimulate an increase in a brand's value and its perceived quality (for instance, when liquor store owners turn up classical music, consumers purchase wine that is more expensive) (Guéguen \& Jacob, 2010);

- the more visitors enjoy music in a cafe, the better they think of this place on the whole (Guéguen \& Jacob, (2001);

- the tempo of music influences time perception and its flow (if a consumer hears quick-paced music while waiting for a telephone operator, it seems that he or she has spent less time waiting and vice versa for slow music) (Milliman, 1986);

- a music genre and the time it is turned on can affect alcohol consumption (one of the studies specified that when classical music is turned on, a number of visitors ordering three and more drinks is higher than when jazz or pop music is turned on) (North, 1996);

- geographical and cultural music characteristics can also have an influence on a person's choice (for example, sailor songs induce consumers to buy seafood; in the French and German wine collection room German wine is preferred if German music is turned on and vice versa) (North, Hargreaves \& McKendrick, 1999);

- if music coincides with the consumption context (its purpose and mood which set an urge towards a product), clients spend more time and money (sale studies at flower-shops indicated that if romantic music is turned on in the pavilion, visitors linger around and the check average is higher) (Wilson, 2003).

Music affects a consumer subconsciously, which is why both a customer and an author of a music style should realize what exactly a recipient will hear in this or that situation - a style, a genre, music characteristics, lyrics etc.

A sound initially lies in the concept of advertising; not a low sound but quite an intrusive one: advertising (reklamo) is translated from Latin as "cry out". It is not without purpose since a sound makes a commercial highly effective. The secret lies in following elementary musical and sound principles.

Sound accompaniment is widely resorted to in all kinds of advertising (Prangishvili, 2014).

In TV commercials music can be used as:

- a background for a good mood;

- commentaries to a plot;

- a song with an advertisement text;

- a sound trademark;

- a factor that attract attention to a commercial (Advertising agency website Pasternak, http://www.pasternakreklama.ru/know/effectadd/).

A research objective is to determine effectiveness of a sound accompaniment in commercials, including its influence on a consumer.

\section{Data for Study and Research Techniques and a Course of Experiment}

The data for study were the TV commercials by Christian Dior, Louis Vuitton, Lacoste, Evian, Spontex, Durex, MTV Erotic:

\begin{tabular}{|c|c|c|}
\hline TV commercial & Sound codes & Meaning \\
\hline $\begin{array}{l}\text { Christian Dior (Secret } \\
\text { Garden Versailles 2012) }\end{array}$ & $\begin{array}{l}\text { Depeche Mode "Enjoy The } \\
\text { Silence" }\end{array}$ & $\begin{array}{l}\text { "All I ever wanted, all I ever needed is here in my arms..." - runs the chorus of the song with a } \\
\text { pompous recognizable and mysterious melody. Jacques Séguéla, one of the producers of the } \\
\text { Dior TV commercial, links splendor and grandeur of Versailles and its gardens to sumptuous } \\
\text { clothes and accessories under promotion presented by magnificent models. }\end{array}$ \\
\hline $\begin{array}{l}\text { L'Invitation Au Voyage - } \\
\text { The Louis Vuitton }\end{array}$ & $\begin{array}{l}\text { John Myrphy - "Don } \\
\text { Abandons Alice" }\end{array}$ & $\begin{array}{l}\text { A mysterious melody without words as though invites you to make a romantic journey. Louis } \\
\text { Vuitton shows itself as a discreet and elegant brand. A one-minute impressionist TV } \\
\text { commercial tells a story about an enigmatic girl as well as comprises a vivid marvelous picture } \\
\text { collection of Paris: the halls of the Louvre, a mysterious key in the girl's hands, a stranger and } \\
\text { a red air balloon. }\end{array}$ \\
\hline $\begin{array}{l}\text { Lacoste 'The Big Leap' - } \\
\text { Life is a beautiful sport }\end{array}$ & $\begin{array}{l}\text { Disclosure - "You and me" } \\
\text { "You and I" }\end{array}$ & $\begin{array}{l}\text { Meaning of the song - "you and I". It is all about feelings, a woman-man relationship. The } \\
\text { melody is full of inner energy. The "Lacoste" brand compares life with sport. A new BETC TV } \\
\text { commercial demonstrates that a date with a final kiss can be as extreme as a jump into the } \\
\text { abyss. }\end{array}$ \\
\hline $\begin{array}{l}\text { The Amazing Spider } \\
\text { Man } 2 \text { - Evian Baby \& } \\
\text { me } 2 \text { - } 2014\end{array}$ & $\begin{array}{l}\text { Yuksek - "Here comes the } \\
\text { hot stepper"; sounds of the } \\
\text { city, a spider's web, a police } \\
\text { car }\end{array}$ & $\begin{array}{l}\text { In a new TV commercial named "The Amazing Baby \& me -2", Spider Man unexpectedly } \\
\text { sees a small version of himself in the window reflection. The beginning of the video is marked } \\
\text { by heroic music usually heard in American films about the world rescue. Then the audience } \\
\text { hears the sounds of a spider's web and the city: car horns, building work so that they realize } \\
\text { the setting is a huge metropolis. But then quite a recognizable melody is turned on, an "Evian" } \\
\text { trademark sign. It is so lively, gay, youthful and prompting to move since the brand slogan } \\
\text { runs "Live young". }\end{array}$ \\
\hline
\end{tabular}




\begin{tabular}{|c|c|c|}
\hline TV commercial & Sound codes & Meaning \\
\hline $\begin{array}{l}\text { Spontex Cleaning } \\
\text { Sponges }\end{array}$ & Sounds: rustling, rubbing & $\begin{array}{l}\text { A high-quality cleaning sponge has to have a thick pile and rub off dirt with ease. The sound } \\
\text { does not tell us what exactly it is but we definitely realize this thing is good at rubbing. It is so } \\
\text { good that even a hedgehog is fond of it. } 22 \text { August } 1999 \text { is marked by a rise of a new TV star } \\
\text { - Ernie the hedgehog. A true seducer is at the crossroads while opting for a new partner: } \\
\text { either a rectangular cleaning sponge or a "Spontex" sponge. He is in two minds but then goes } \\
\text { for the latter but not only because of its colour and beauty but also because it is better at } \\
\text { rubbing. The show comes to an end with Ernie's rolling to the song "Put your hand on my } \\
\text { shoulder" by Paul Anka. }\end{array}$ \\
\hline Durex & $\begin{array}{l}\text { Sounds: rubbing, creaking, } \\
\text { squeaking, shuffling, striking }\end{array}$ & $\begin{array}{l}\text { What else is it supposed to be heard in a contraceptive TV commercial, if not rubbing and } \\
\text { creaking? The Durex video made the most of this consumer stereotype. }\end{array}$ \\
\hline MTV Erotic, 2001 & $\begin{array}{l}\text { Imitative sounds of women's } \\
\text { sexual behaviour }\end{array}$ & $\begin{array}{l}\text { It turned out that a well thought-out TV commercial can do without an appealing picture. } \\
\text { Sometimes a sound is more than enough. Unexpectedly the majority of the audience } \\
\text { considered a video with only white words against a black background, groans and sighs to be } \\
\text { the best out of all. The creators' terrific sense of humour together with their life experience } \\
\text { definitely made a hit with the public. }\end{array}$ \\
\hline
\end{tabular}

All the TV commercials were subdivided into 2 groups:

- a commercial with a song accompaniment;

- a commercial with imitative words, natural sounds of the environment and the city.

A focus group consisting of 40 people from two age groups: the younger generation (17-30 years old) and middleaged people (30-50 years old) were invited to participate in the experiment. The objective of conducting an experiment on the focus group is to determine effectiveness of a sound accompaniment in commercials. A research technique is an opinion poll.

The crux of the experiment lies in presenting a TV commercial without a video but with a sound accompaniment.

The testing consisted of 2 questions:

- What is being advertised?

- What emotions do you get from listening to the sound accompaniment?

\section{Results}

The experiment gave the following results:

Christian Dior. $45 \%$ of interviewees considered the topic of the commercial to be a fashion show; that is to say the majority succeeded in grasping the topic of the video via sound. $25 \%$ gave the result close to the first group, saying it had to do with fashionable clothes. $15 \%$ of the people questioned deduced that the video was all about high-end cars because of a pompous well-known song. 10\% came to a conclusion that a travel agency was advertised, and only 5\% gathered that the crux of the commercial was a foreign film. $90 \%$ of the group took a positive view on the accompaniment since they heard the song more than once. $10 \%$ held the melody neutral.

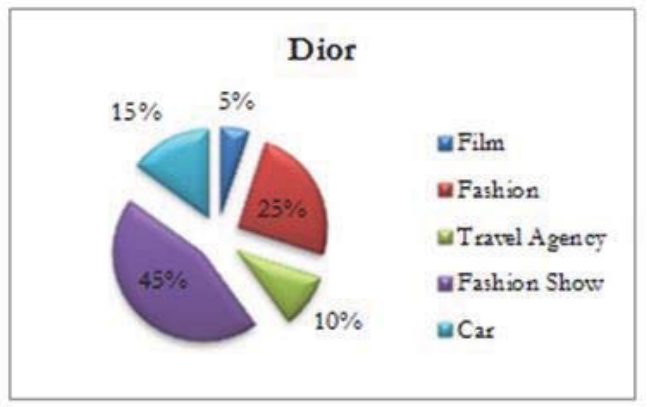

Figure. 1. Poll Results Advertising of Dior

Listening to the second commercial (Louis Vuitton) revealed that $40 \%$ of the group considered it to be a video about a journey. 25\% answered that it had to do with theater. In equal parts, 15\% each, the group concluded the video displayed a circus or antique jewellery commercial. $5 \%$ only voted for a quest game. According to the results, no one could say exactly what was advertised in the video. But the majority caught the philosophy and main point of the commercial the brand's slogan is "an invitation to a journey". $45 \%$ of the audience enjoyed the music, stating it was pleasant. And $45 \%$ said the melody appealed to the ear. 


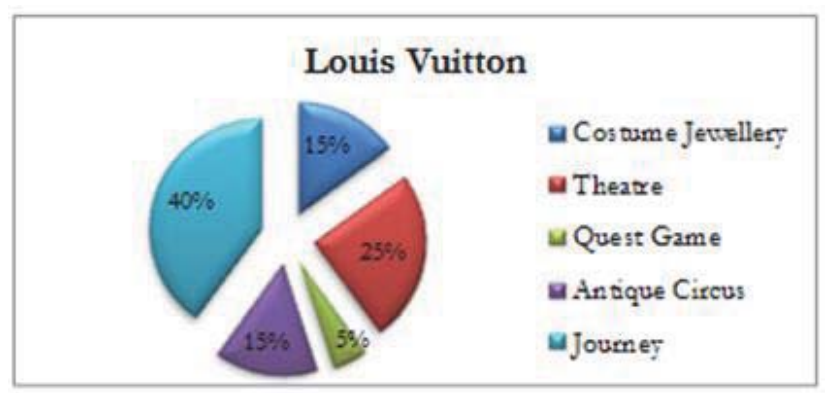

Figure. 2. Poll Results Advertising of Louis Vuitton

By results of the Lacoste commercial showing it is apparent that the majority put two and two together. $45 \%$ of the group supposed the video to be a clothes commercial. $35 \%$ concluded that it was a dancing school video, justifying that by a swift lively melody. Finally, $20 \%$ of the people stated that was an underwear commercial. The video's accompaniment appealed to $95 \%$ of the target group. Only $5 \%$ treated it indifferently.

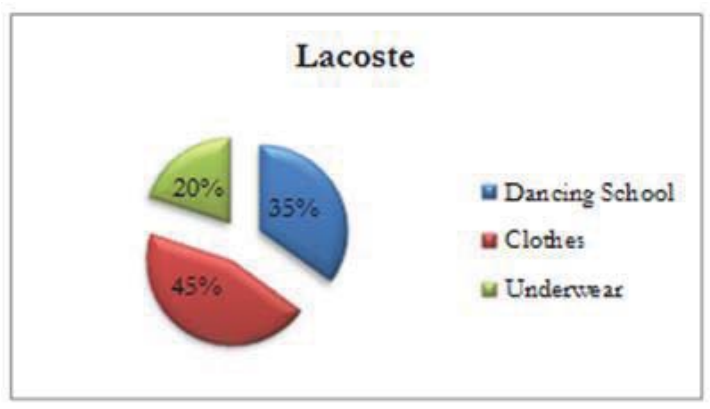

Figure. 3. The results of the survey on advertising of Lacoste

Judging by the sounds in the Evian commercial $45 \%$ of the focus group drew a conclusion that the video presented a film. $35 \%$ guessed right that it was a water commercial due to a familiar melody. $15 \%$ decided that various hand tools were advertised because of the city sounds and road traffic noise. $5 \%$ defined it as a Chinese food commercial. $90 \%$ of all the interwiewees had already heard the music, which resulted in positive attitude to it. $10 \%$ only held it neutral.

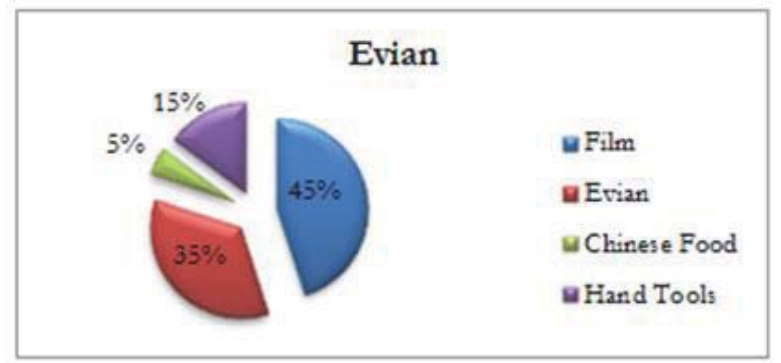

Figure. 4. The results of the survey on advertising of Evian

Spontex. Judging by the melody in this commercial $85 \%$ of the group deduced it was all about junk food due to it being abundant in rustling sounds. $15 \%$ considered it to be a video about stationery. Listening to the sound alone, without any video series, didn't hint at the product under promotion. 50\% got annoyed with the sounds, $45 \%$ said that the sounds were unpleasant and only $5 \%$ of the group treated them indifferently. 


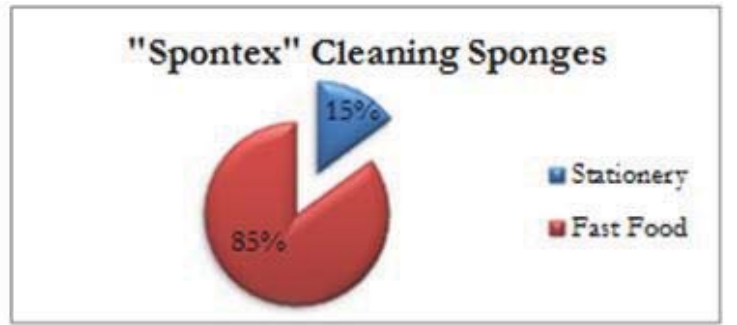

Figure 5. The results of the survey on advertising of Spontex

Durex. Half of the group defined the product under promotion. $25 \%$ came to a conclusion that an event agency was advertised due to balloon sounds, $15 \%$ of the targer audience supposed it to be a rubber commercial because of rubbing sounds. $85 \%$ were made to laugh by the video and $15 \%$ of the group regarded the melody as ear-catching.

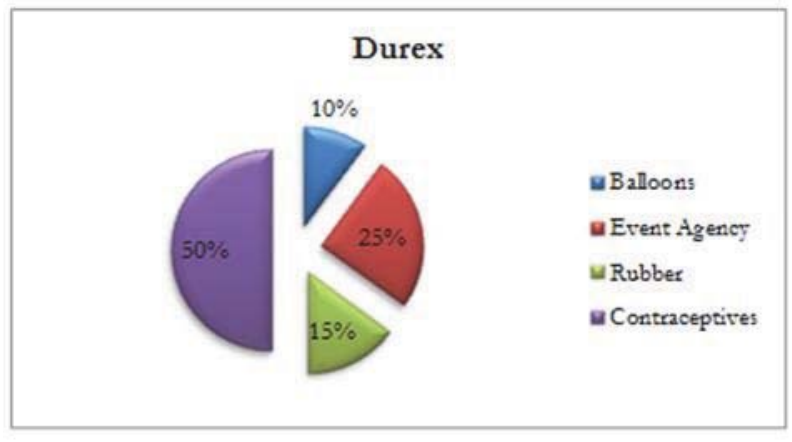

Figure 6. Poll Results Advertising of Durex

MTV Erotic. Judging by the sounds in the commercial it was not that difficult to guess the product. $80 \%$ truly stated that the adult TV channel was presented. $15 \%$ answered quite closely that the video had to do with phone sex. Only $5 \%$ of the group supposed it to be a creative food commercial. 65\% admitted that the video drew an audience and 35\% got embarrassed by the sounds.

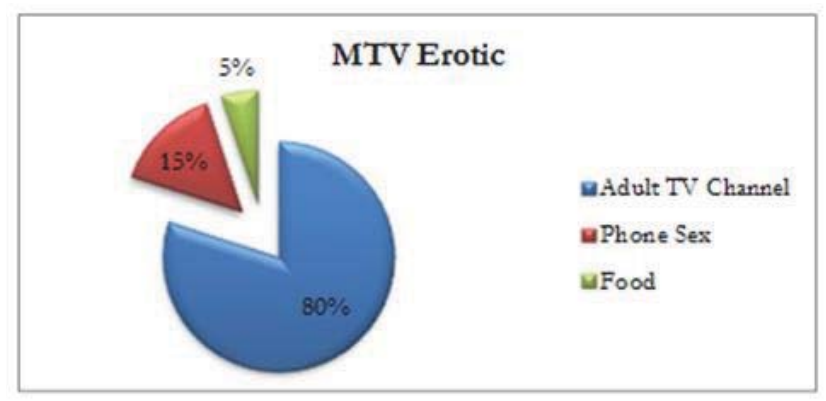

Figure 7. Poll Results Advertising MTV Erotic

\section{Discussion of the Results}

It is on the face of it that sounds in commercials are of paramount importance. Their influence on viewers and their emotions is definitely huge. A sound, together with a video series, delivers necessary information and complements a picture. As appears from the experiment, the majority managed to grasp what was being advertised with the help of sounds or were very close in their guesses.

The sound code brought the necessary information in 6 videos out of 7 . 
The sound in the "Spontex" commercial didn't get across to the audience. Subsequently it is difficult to perceive it by ear only which means that this commercial is effective with both visual and sound backing.

$53 \%$ of the group managed to catch the main idea in all the 7 videos.

$47 \%$ didn't catch the main point of the commercials.

$88 \%$ displayed a positive attitude to the music accompaniment in the videos.

$12 \%$ held the videos neutral.

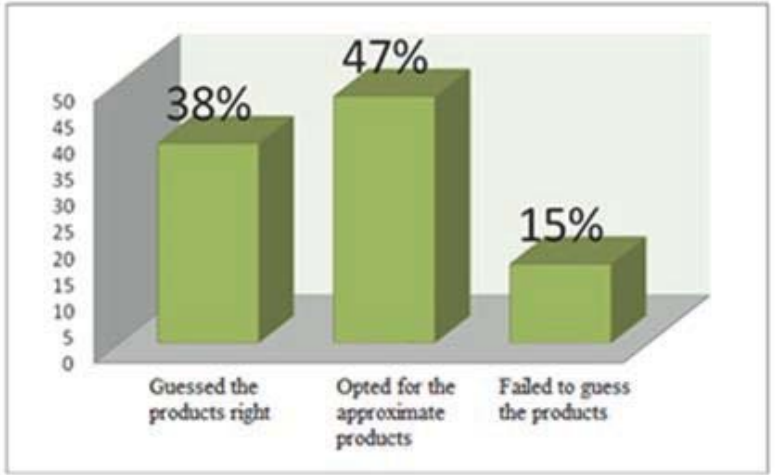

Figure 8. Awareness promotional product without visuals

Based on the results of the experiment, $38 \%$ of the respondents guessed the product under promotion right without resorting to watching a commercial, $47 \%$ named the products approximated to the ones presented in the videos.

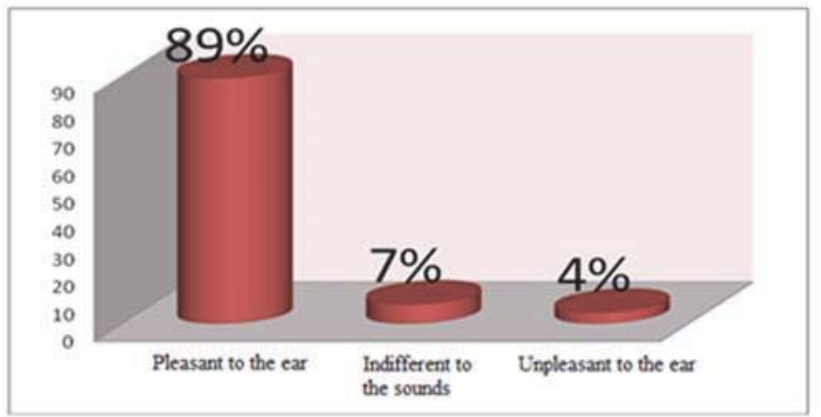

Figure 9. Evaluation scale

In $89 \%$ of cases the sounds left pleasant impressions; a number of negative reactions is close to zero.

Today people necessitate amusements all the time so it gets harder and harder to lure them by a picture only. Special effects do not hold the viewers spellbound any more, which is why specialists attempt to introduce more sounds in commercials. This marketing tool has not been used to the fullest yet which implies more opportunities and consequently more new clients.

\section{Conclusion}

Sound codes in advertising are a relatively new but at the same time highly significant trend, which can't be overlooked in advertising communication. A sound helps to convey the meaning, idea and philosophy of advertising. It triggers emotions that can't be aroused by a video series only.

The experiment demonstrated that an appropriate well-assorted music line in advertisement draws attention of its recipient, fosters notability and creates a positive attitude towards a product under promotion.

On the other hand, a noise accompaniment appears to be a potent expressive means that evokes the worldly sounds in music. Vividness and expressiveness together with a competent choice of noises build a more vibrant and appealing image of a product. 
Collating commercial influence with a song and noise accompaniment, it is noteworthy that the former produces a stronger aesthetic impact on a person urging an emotional experience and due to this ensures a product's notability and a willing to purchase it. The latter more often creates an effect of involvement, gives a comic tinge but works better with a video series.

In view of the above-mentioned, the sound accompaniment in advertising can exert influence on the target audience effectively being sometimes even more important than a video series. The issue has a practical significance for advertisers and PR managers.

\section{References}

Batra, R., Aaker D.A. \& Myers J.G. 1999. Advertising Management. 5th Edition - M. SPb.: Williams. pp. 784.

Goncharov, P.A. \& D.D. Basov. Audio branding elements design: Modern approach

Grachyova, S.G. 1997. Advertising: Sociological aspects of analysis - 22.00.08. M.

Pishcherskaya, E.N. 2011. Strategic potential of the banner advertising text, - 10.02.19. Irkutsk.

Pocheptsov, G.G. 2000. Communicative techniques of the XX century - M.

Prangishvili, I.G. 2014. Linguistic peculiarities of AMBIENT MEDIA // Philological Sciences. Theoretical and practical questions. №8. pp. 126-129.

Advertising agency website pasternak URL: http://www.pasternak-reklama.ru/know/effectadd/ (access date 21.01.2015)

Feofanov, O.A. 2000. Advertising: New techniques in Russia.- SPb.

Areni, C.S. \& Kim D. 1993. The influence of background music on shopping behavior: classical versus top-forty music in a wine store. Advances in Consumer Research, Vol. 20, pp. 336-340.

Guéguen, N. \& Jacob C. 2001. L'effet des caractéristiques d'une musique d'attente téléphonique sur la perception du délai d'attente des interlocuteurs. Revue Européenne de Psychologie Appliquée, Vol. 51, pp. 77-84.

Guéguen, N. \& Jacob C. 2010. Music congruency and consumer behaviour: an experimental field study. International Bulletin of Business Administration, Iss. 9, pp. 56-63.

Milliman, R.E. 1986. The influence of background music on the behavior of restaurant patrons. Journal of Consumer Research, Vol. 13 (2), pp. 286-289.

North, A. 1996. The effects of music on responses to a dining area. Journal of Environmental Psychology, Vol. 16 (1), pp. 55-64.

North, A., Hargreaves D. \& McKendrick J. 1999. The influence of in-store music on wine selections. Journal of Applied Psychology, Vol. 84, pp. 271-276.

Wilson, S. 2003. The effect of music on perceived atmosphere and purchase intentions in a restaurant. Psychology of Music, Vol. 31, pp. 93-112. 
ISSN 2039-2117 (online) ISSN 2039-9340 (print)
Mediterranean Journal of Social Sciences MCSER Publishing, Rome-Italy
Vol 6 No 3 S4 May 2015 